Preprints of the

Max Planck Institute for

Research on Collective Goods

Bonn 2017/4

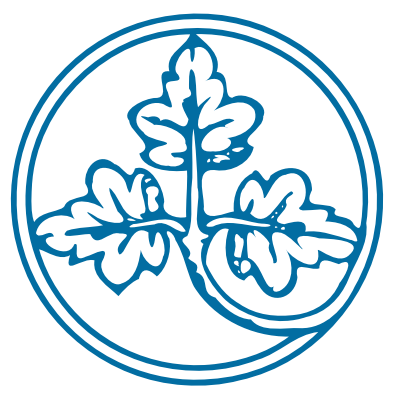

The Valuation of Moral Rights:

A Field Experiment

Stefan Bechtold

Christoph Engel

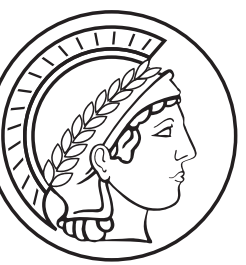




\section{The Valuation of Moral Rights: A Field Experiment}

Stefan Bechtold / Christoph Engel

March 25, 2017 


\title{
The Valuation of Moral Rights: A Field Experiment ${ }^{*}$
}

\author{
Stefan Bechtold / Christoph Engel
}

March 25, 2017

\begin{abstract}
U.S. intellectual property law is firmly rooted in utilitarian principles. Copyright law is viewed as a means to give proper monetary incentives to authors for their creative effort. Many European copyright systems pursue additional goals: Authors have the right to be named as author, to control alterations and to retract their work in case their artistic beliefs have changed. Protecting these "moral rights" might be justified by the preferences of typical authors. We present the first field experiment on moral rights revealing the true valuation of these rights by over 200 authors from 24 countries. A majority of authors are not willing to trade moral rights in the first place. They demand substantial prices in case they decide to trade. The differences between authors from the U.S. and Europe are small. These results call into question whether moral rights protection should differ across the Atlantic and whether a purely profit-based theory of copyright law is sufficient to capture the complex relationship between human behavior and creativity.
\end{abstract}

JEL: C93, D03, K11, L82, O31, O34, O38

Keywords: intellectual property, copyright, creativity, invention, moral right, willingness to pay

Stefan Bechtold is Professor of Intellectual Property at ETH Zurich, Switzerland. Christoph Engel is Director at the Max Planck Institute for Research on Collective Goods in Bonn, Germany. The authors would like to thank David Abrams, Oren Bar-Gill, Chris Buccafusco, Rochelle Dreyfuss, Ezra Friedman, Jeannie Fromer, Gabriel Gertsch, Olga Gorelkina, Hanjo Hamann, Daniel Ho, Heiko Karle, Lisa Larrimore Ouellette, Mark Lemley, Matthias Leistner, Vardges Levonyan, Martin Schonger, Matt Spitzer, Kathy Zeiler, and Albert Yoon; conference participants at the Experimental Methods in Legal Scholarship Workshop 2016 at UCLA, and the Conference on Empirical Legal Studies 2016 at Duke; as well as seminar participants at ETH Zurich and the universities of Bonn, Copenhagen, Duisburg, Hamburg, Michigan and Zurich for helpful feedback. Malik El Bay provided invaluable support in programming and running the experiment, and Himanshu Jain, Azar Sang Bastian and Miriam Tinner assisted in the recruitment of participants. 


\section{Introduction}

In 2011, the Court of Appeals for the 7th Circuit rendered a decision about a public park in its home town. Landscape artist Chapman Kelley had installed a large wild flower display in Grant Park in downtown Chicago some 25 years ago. When Millennium Park was created in the early 2000s, the Park District reduced the size of Kelley's installation to less than half of its original size, remade the originally elliptical flower beds into rectangles, replanted some wild flowers and added other planting material. Chapman Kelley objected to this reconfiguration and sued the Park District under an exceptional copyright statute: the Visual Artists Rights Act of 1990 (VARA). He estimated the value of damaged plants at \$1.5 million and requested \$25 million for violations of his moral rights. The court rejected the claims. While recognizing that Kelley's garden may be a work of postmodern conceptual art, it held that the garden lacked the necessary authorship and fixation to receive protection under VARA (Chapman Kelley v. Chicago Park District, 635 F.Rep.3d 290, 304 (7th Cir. 2011)).

European artists have had more luck. After the fall of the Berlin Wall, the German government decided to build a new main railway station for Berlin close to the Brandenburg Gate at a cost of about 1 billion Euros. The well-known German architect Meinhard van Gerkan was commissioned by the German railway company Deutsche Bahn to design the station. When the railway company later decided to replace a planned vaulted ceiling with a flat ceiling, the architect objected. The dispute went to court and the Berlin regional court held that the unauthorized change in the station design by Deutsche Bahn was a violation of the architect's moral right of integrity under German copyright law. Even though the contract between the railway company and the architect included a provision according to which the company could apply changes to the design, replacing the ceiling was not covered by the provision as it defaced the copyrighted work. The court held that Deutsche Bahn was required to remove the flat ceiling at an estimated cost of 44.5 million Euros. ${ }^{1}$

In 1991, French director Bruton Boussagol produced Samuel Beckett's "Waiting for Godot" for the annual Avignon Festival. He decided to cast the four lead male roles with four actresses. When contacted, the heirs of the deceased author would not grant the necessary copyright licenses because it had been the desire of Samuel Beckett that the play should not be performed by female actresses. When the play was performed nevertheless, the heirs sued the director and his theater company for an alleged infringement of Beckett's post-mortal moral rights. The High Court of Paris held in 1992 that the production had violated Beckett's right of integrity as enshrined in French copyright law, and that it was not upon the judge to scrutinize the desire of the author. It ordered the director and his theater company to pay a symbolic

1 Landgericht Berlin, November 28, 2006, case 16 O 240/05, GRUR 2007, 964. The parties later settled the dispute out of court at an undisclosed sum without the ceiling being replaced. For a more extended discussion of the moral rights of architects, see (Grünberger and Dietz 2015: §7[2][b]). 
damage of one Franc to the heirs, and to publish the judgment in three newspapers at a cost of up to 36,000 Francs. $^{2}$

The different attitudes towards artists' interests in the integrity of their artwork on both sides of the Atlantic are rooted in an important difference between the two copyright systems. Copyright law in Continental Europe is not only, and not even primarily, meant to create monetary incentives for artistic creation. Rather, European copyright law starts from the desire of artists for recognition, with pecuniary remuneration from the market being only one facet of recognition. In that spirit, continental European copyright systems typically grant authors a right to be named (right of attribution), to object to unauthorized alterations of their works (right of integrity) and to retract a work if their artistic convictions have changed. These socalled "moral rights" are conceptually distinct from - although practically often intertwined with - the economic exploitation rights granted by copyright protection, such as the rights of reproduction, distribution, public performance and making the work available to the public. France and Germany are the two European countries with the strongest protection of moral rights (Sundara Rajan 2011: 49, 51-88). Traditionally, U.S. copyright law has not recognized such rights. Although the U.S. granted moral rights to visual artists in 1990 when it joined the Berne Convention for the Protection of Literary and Artistic Works, the overall protection for moral rights under U.S. law is significantly weaker than under many of its European counterparts.

Copyright scholars have been debating which system is preferable for a long time: Should copyright law recognize the non-pecuniary interests of authors or is society better off by not legally protecting such rights? The debate touches on foundational issues of copyright law: Has copyright law primarily, or even exclusively, a forward-looking purpose? Does it react to the fact that information is a pure public good (nobody can be excluded from relying on information; if one person picks up a piece of information, it does not become less valuable for the next person)? Is temporal monopoly the technology for making information marketable? Or does copyright (also) have a backward-looking purpose? Do artists feel betrayed if others just copy their works? Does the law step in to protect their legitimate expectation of recognition, both pecuniary and non-pecuniary? In a broader sense, this debate also touches upon the distinction between utilitarian and deontological motives. The U.S. approach follows naturally if one interprets copyright law as a technology for overcoming market failure. The continental European approach follows naturally if one interprets copyright law as a reflection of artists' private and social identity. Yet, ultimately, one could also justify the protection of moral rights on utilitarian grounds (Fromer 2012). This would require a definition of utility that transcends profit and includes non-monetary sources of utility, such as autonomy, selfexpression and social recognition.

2 Tribunal de Grande Instance de Paris, 3rd chamber, October 15, 1992, R.I.D.A. 1993, 225; see also Lucas, Kamina et al. (2015: §7[1][c][i]) (also pointing to later diverging French case law). 
This debate has remained largely theoretical. Apart from one experimental study with a different focus, scope and methodology (Sprigman, Buccafusco et al. 2013), no data are available to assess the desirability of moral rights protection in an empirically informed way. Our study intends to fill this gap. To the best of our knowledge, we present the first incentivecompatible field experiment eliciting preferences of authors for moral rights from various countries worldwide, and comparing the preferences of U.S. and European authors. To the best of our knowledge, we also present one of the first controlled field experiments in intellectual property research. We find that a majority of authors in our study are not willing to trade moral rights in the first place. If there is trade, authors demand substantial prices. The differences between U.S. authors and their European counterparts are small. This suggests that the different legal traditions neither reflect systematic differences in preferences, nor that the revealed preference of European artists for moral rights protection is an epiphenomenon of the fact that European legal systems protect these rights.

The paper proceeds as follows. Section 2 provides the relevant background and presents our hypotheses. Section 3 discusses the design of our field experiment, while Section 4 describes our data collection efforts. Section 5 presents the results, which are then discussed in Section 6. Section 7 concludes.

\section{Background and Hypotheses}

Moral rights were introduced in French copyright law in the early 19th century (Strömholm 1983: 10). The French intellectual property code protects the authors' moral right to disclose their work to the public; to attribute their authorship; to protect the integrity of their work; and to retract their work (Art. L 121-1 to 121-4 Code de la Propriété Intellectuelle). If the right of integrity is violated, authors do not have to prove that the allegedly infringing activity truly harmed their reputation or honor. Rather, French law applies a subjective standard: It is for the author to define the scope of the right (Lucas, Kamina et al. 2015: §7[1][c][i]). Moral rights in France are not limited in time. Rather, they are perpetual in nature. They can also, in principle, neither be waived nor transferred (Art. L 121-1). This has led the highest French appeals court to enjoin the broadcast of the American film noir "The Asphalt Jungle” in a colorized version on French television. The court held that the broadcasting of the colorized version violated the integrity right of the movie's screen writer and director. While both had entered into contracts under U.S. law effectively waiving their moral rights, the court held that such waiver was not enforceable under French law (Cass. Civ. I, May 28, 1991, Rec. D. 1993, 197). ${ }^{3}$

The German Copyright Act protects authors in their intellectual and personal relationship to the work (§11 Urheberrechtsgesetz). Before enumerating various exploitation rights in $\S \S 15-$

3 For a discussion on the scope of the inalienability and unwaivability doctrines, see Lucas, Kamina et al. (2015: §7[4]). 
23, the Act lays out the main moral rights in §§ 12-14: the right to disclose the work, to attribute authorship and to protect the integrity of the work. In addition, German law enables authors to retract their work if their artistic beliefs have changed ( $\$ 42$ Urheberrechtsgesetz). Unlike French law, German copyright doctrine has adopted a "monistic approach,” according to which both the moral and economic interests of authors are so heavily intertwined that they cannot be separated from each other. This not only means that moral rights can neither be transferred nor waived under German copyright law, but also that copyright as a whole is neither transferable nor waivable (Grünberger and Dietz 2015: §7[1]). Unlike in France, German moral rights are not protected perpetually, but expire 70 years after the author's death ( $\$ 64$ Urheberrechtsgesetz).

U.S. copyright law adopts a very different position. Traditionally, the U.S. Copyright Act did not include any specific protection of moral rights. With the accession of the U.S. to the Berne Convention for the Protection of Literary and Artistic Works, a limited protection of moral rights was created for visual artists in the Visual Artists Rights Act (VARA) of 1990. Authors of works of visual art have a right of attribution, a right to protect the integrity of their work, and a right to prevent the destruction in case of works of a recognized stature (17 U.S.C. $\S 106 \mathrm{~A}(\mathrm{a}))$. These rights are inalienable, but can be waived (17 U.S.C. §106A(e)). They expire when the author dies (17 U.S.C. §106A(d)). Authors other than visual artists do not benefit from a similar protection of moral rights. Outside the limited scope of VARA, various doctrines in U.S. federal and state law may protect some moral interests of authors on a case-bycase basis. However, U.S. law generally provides far less protection of moral rights than its European counterparts. ${ }^{4}$

It should come as no surprise that Continental European copyright systems provide much stronger protection for moral rights than U.S. law. European copyright theory is based on a natural rights conception. In the 19th century, the notion that natural rights existed independently of the form given by positive law, Immanuel Kant's writings on personality rights and the Romantic notion of authorship coalesced into a copyright doctrine which puts the close bond between the authors and their work at its heart (Adeney 2006). By contrast, U.S. copyright protection is based firmly on utilitarian, and more specifically, profit-maximization grounds. According to the U.S. constitution, intellectual property rights are granted " $[\mathrm{t}] \mathrm{o}$ Promote the Progress of Science and useful Arts” (U.S. Const. art. I, § 8, cl. 8). If an area of copyright law cannot be reconciled easily with the notion that the government must provide a property right to creators in order to incentivize their creative output, it is often regarded with suspicion in the U.S. (see, e.g., Lemley 2015).

Accordingly, U.S. scholars often have a critical if not dismissive view of moral rights. Landes and Posner (2003: 276-280), for example, argue that moral rights are either unnecessary or do more harm than good. Lemley (1997: 1031-1033) argues that moral rights protection impedes the productive uses of copyrighted works by increasing transaction costs. Adler (2009) asserts 
that moral rights threaten artistic discourse by vesting too much control with artists. Other U.S. scholars have been more receptive to moral rights protection, though. Hansmann and Santilli (1997) show that moral rights may enable authors and owners of artwork to control reputational externalities. Fromer (2012) argues that moral rights can support a utilitarian copyright system in the form of "expressive incentives" (see also Lemley 2015: 1340). More generally, moral rights protection has gathered increased interest from U.S. scholars in recent years (Fisk 2006, Rosenthal Kwall 2010, Merges 2011: 156-158).

While the justification and scope of moral rights is vigorously debated on both sides of the Atlantic, this debate has remained largely a theoretical one. As in other areas of intellectual property law, there is a dearth of empirical data to complement the theoretical debate. We have been able to spot two pertinent papers. Spellman and Schauer (2009) report the results of two vignette studies in which participants express their feelings about changes made to an artwork and to a non-art product, each created by a third party. They find that participants express much stronger objections to changes made to the artwork than to the non-art product, that the objections increase if the artwork expresses a social opinion and that participants' political opinions and involvement in art affect their judgment. Sprigman, Buccafusco et al. (2013) conduct three contests in which they elicit reservation prices concerning publication and attribution rights. The subjects cannot decide whether to sell these rights. Rather, they participate in a contest and sell the opportunity to win the contest prize to a third party. Subjects are recruited via Amazon Mechanical Turk as well as a photography magazine and affinity group. They are told at the end of the experiment that no trade has actually occurred. Sprigman, Buccafusco et al. find that their participants have a substantial valuation for the attribution right.

Our approach goes beyond this evidence in multiple dimensions. First, we are gathering data on the three most relevant types of moral rights. Second, we conduct a field experiment. We use actual authors as subjects who are not aware that they are participating in an experiment, and we buy copyrighted works and related moral rights from authors. Thereby, real trade occurs with real authors. These design choices should alleviate external validity concerns that could be raised against the previous vignette studies. Third, unlike earlier studies, we use an international subject pool, enabling us to analyze preference variation across countries. Given the significant differences in moral rights protection on both sides of the Atlantic, this is an important aspect to analyze. Finally, and most importantly, our experimental design uses an incentive-compatible elicitation mechanism which ensures that the valuations which we elicit from our participants correspond to their true valuations.

We are interested in three questions. First, we want to test empirically whether - and at what price - authors are willing to grant not only an exclusive license to reproduce their work, but also the right to (1) use their work without mentioning their name (thereby giving up their attribution right); (2) change their work (thereby giving up their right of integrity); and (3) 
delete their work (thereby giving up their right of retraction). ${ }^{5}$ As we are interested in whether authors are willing to trade moral rights at all (see also Bartling, Fehr et al. 2014), we perform separate tests for the authors' willingness to trade these rights and for the prices they demand for such trade.

Second, given the varying scope of moral rights protection on both sides of the Atlantic, we want to analyze whether authors from different jurisdictions have different preferences concerning moral rights. The arrow of causality could point in either direction: U.S. law might reflect that U.S. authors do not care (or very little) about moral rights, or the desire of European authors for moral rights protection could have been shaped by the fact that these rights are protected in their countries.

Third, we want to test whether authors' willingness to trade and reservation prices differ depending on whether they trade rights in a non-transferable way (so that the licensee cannot transfer the rights to a third party) or a transferable way (so that the licensee can). This is of interest for three reasons:

a) As explained in the introduction, some legal systems that protect moral rights also make them inalienable. This fits a normative theory that grounds moral rights in a deontological right of recognition (but could also be captured by utilitarian "identity utility", see Akerlof and Kranton 2000, Bénabou and Tirole 2011). We investigate whether inalienability reflects a preference of typical authors.

b) If an author demands a very high price for a moral right, this shows that she values this right highly. But we cannot necessarily say whether she is happy to commercialize the right provided the price is high enough, or whether she is opposed to commercialization of the right altogether. If the author is willing to sell a moral right in a non-transferable way, it could be that the high price compensates her for a non-monetary harm (along the lines of a pain and suffering claim). If, however, she is willing to sell the right in a transferable way, we know that she has consented to turning the moral right into an object of trade, thereby ruling out the latter interpretation. By eliciting separate reservation prices for transferable and non-transferable moral rights, we thereby can distinguish between these two interpretations.

c) Even if a copyright system does not protect moral rights, authors could protect these rights by contract, i.e. by reserving them in license agreements. Yet, the resulting protection would only be bilateral. If the original buyer sells the copyright to a third party, this party is not bound by the original contract due to lack of privity. If the original buyer sells the copyright without also imposing the moral right on the third party, he may violate his original contract with the author. Depending on the legal system, it may be

5 Note that we directly test the solution of the U.S. VARA, i.e. the right to prevent the deletion of the work. We thereby focus on a core set of moral rights. Some European countries protect the even more encompassing right of retraction. 
difficult to write or enforce a contract in which the moral right runs along with the license so that the author could force the original buyer to enforce the moral right against the third party. A protection of moral rights by a property right alleviates these concerns. Eliciting the willingness to pay for giving a transferable moral right provides us with an indication of how important such protection by a property right may be for authors.

This discussion leads us to the following hypotheses. If Continental European copyright law reflects a widespread preference for the protection of moral rights, we should see

Hypothesis 1:

a) Individuals are less likely to trade moral rights than a transferable right to reproduce the photo; and

b) Individuals who are at all willing to trade moral rights ask for a higher price than for the transferable right to reproduce the photo. ${ }^{6}$

If Continental European authors have stronger preferences for moral rights than U.S. authors, we should see

Hypothesis 2:

a) The willingness to trade moral rights is less pronounced in France or Germany than in the U.S.; and

b) Individuals in France or Germany who are at all willing to trade moral rights ask for a higher price than individuals from the U.S.

\section{Design}

Economic experiments are often run in a laboratory. This has the advantage of high experimental control. One may perfectly construct the environment. One may perfectly balance the sample according to whatever criteria seem appropriate. But there is a price for cleanliness. Concerns about external validity may limit the generalizability of experimental results. Most economic experiments also test a convenience sample (students), while the research question concerns the general population, or even other, specific groups.

For our research question, the price of running a lab experiment would be high. We want to estimate individuals' willingness to trade and their reservation prices for moral rights in their intellectual achievements. It is already difficult to implement creative tasks in the lab. Creating a sense of ownership for one's creativity is even more challenging in the lab. This is why we accept the inevitable slight loss in internal validity and run a field experiment (for background, see Al-Ubaydli and List 2015). While we are not the first to use a field experi-

6 We have no directed hypothesis for the relationship of these reactions to alternative moral rights or to transferable vs. non-transferable rights. 
ment to elicit reservation prices for contractual terms (Listokin 2010), to the best of our knowledge, this is the first study to use such a design for intellectual property research.

We set up a tailor-made web site ("The Photo Challenge”) on which we announced that a research organization is seeking photographs of artistic value. We were interested in whether and at what price participants sell us their photos and attached moral rights. Participants were recruited online through various social media channels. We placed ads on Facebook and Google, contacted bloggers of important photography web sites and participated in photography blog discussions. It turned out that the most effective way to recruit participants on an international basis was Facebook ads, through which we recruited most of our participants. ${ }^{7}$ The Facebook ad system made sure that our ads were only displayed to Facebook users with an expressed interest in photography.

Once a user had become aware of our Photo Challenge, they went to our web site and read some instructions. We declared that all shots submitted would be evaluated by a jury, but that the jury would only assess whether the photo is on topic and has more than minimal artistic value. We pledged to buy all the photos that met those two conditions at a guaranteed price of $\$ 10 .{ }^{8}$ We asked participants to decide whether they were willing to additionally give us any moral rights and, if so, to define the minimum price (their willingness to accept). Thereafter, we asked participants for their PayPal account information and administered a questionnaire. Payment was later performed via PayPal. Please refer to the screenshots in Appendix A for details.

We want to investigate copyright owners' preferences for the non-pecuniary dimensions of intellectual property. We reflect this by a within-subjects design. Table 1 summarizes our baseline and the seven treatments. In the baseline condition (b), the copyright owner grants an exclusive, transferable license (we buy the exclusive, non-transferable license (a) from all participants at \$10). In further conditions, we additionally ask for the right not to mention the name of the photographer when using the picture, for the right to destroy the picture (since the license is exclusive, the photographer would not be allowed to use the picture either) or for the right to alter the picture. These additional rights are alternative, not cumulative. We ask separately for the right to transfer either right to an undisclosed third party.

7 A typical Facebook ad would read “The Photo Challenge has started! You have 10 days to submit your photo related to the topic 'Nature'. Every chosen photo gets at least \$10, and you may earn more. Participate now at http://www.photo-challenge.org.”

8 By fixing the price at which we buy the exclusive license to reproduce the photo, we avoid spillovers from the participant's valuation of the photo as such to her valuation of moral rights related to the photo. If a participant submits a photo with some artistic value and on the right topic, she knows that she will be paid \$10 for an exclusive non-transferable license to use the photo. The fixed price of \$10 also serves as a screening device. We screen out photographers with a much higher economic valuation for their photograph. We induce a reference payment against which participants can compare the value of the moral right in question. 


\begin{tabular}{|l|l|l|}
\hline & non-transferable & transferable \\
\hline reproduction & a: bought from all participants at \$10 & b: serves as baseline \\
\hline attribution & & \\
\hline deletion & & \\
\hline integrity & & \\
\hline
\end{tabular}

Table 1: Treatments

For each cell, except for the exclusive, non-transferable license to reproduce, each participant decides whether she is at all willing to trade. If yes, she also defines the minimum price she requires for trading.

We have two dependent variables: the categorical willingness to trade the respective right and, conditional on this willingness to be positive, the price the individual asks for. With our second dependent variable, we want to elicit individuals' reservation prices. We cap the reservation prices at $\$ 100$ to cater for outliers and for budgetary reasons. If an individual indicates that she is not willing to trade the right in question, this may, therefore, mean two things: The individual would never trade this right, or she would only be willing to sell it at a price above $\$ 100$. While we cannot exclude the second interpretation with our design, we note that it is not very likely. The price of $\$ 100$ is ten times that which we are paying for the nontransferable exclusive license to reproduce the photo. We only consider participants who are, at least, willing to trade this right (i.e. are willing to use the photograph commercially at all) at a fixed price of $\$ 10$.

Social sciences differ in their attitude towards self-report data (Hertwig and Ortmann 2001). While such data is routinely used in psychology, sociology and criminology, economists tend to be skeptical. We do not mean to be religious about this point. Self-report data can be the only available source of information. One can gather much richer data from one and the same participant in a questionnaire. It is easier to evoke and manipulate context in a questionnaire. However, for our particular research question, we believe that self-report data would be less than perfect. We do not only want to learn whether participants care about moral rights; who would say no? Rather, we want to learn whether they care at all sufficiently to not trade the additional right and, thereby, forego the possibility of earning an additional amount of money up to $\$ 100$. If we just asked, there would be a problem of credibility. By contrast, if we have participants actually trading (or not), they feel the financial consequences of their valuation of the moral right directly. Moreover, provided participants are at all willing to trade, we want to estimate their reservation prices. It is well-known that statements about willingness to accept (which is what we want to measure) are notoriously unreliable (Tversky, Sattath et al. 1988, Sunstein, Kahneman et al. 2002). This problem is remedied if participants engage real money.

We use the procedure that is standard in experimental economics for eliciting willingness to pay (or to accept) (Becker, DeGroot et al. 1964). Technically, the mechanism is a (reversed) second-prize auction (Vickrey 1961, Clarke 1971, Groves 1973), which is known to be (dominant strategy) incentive-compatible. Each participant indicates the minimum price at which she is willing to trade the right in question. We buy a single right, from the participant who has asked for the lowest price. We pay this participant the second lowest price which has been 
indicated by another participant in the auction. If a participant underbids, she increases the likelihood of winning the auction, but risks that another participant truly has an even lower valuation, and she will only receive this price. If the participant overbids, she risks not selling the right at all.

In order to avoid incentive-compatibility issues inherent in second-prize auctions with multiple heterogeneous items (Ausubel 2008: 299-301, Clarke 1971, Groves 1973), we adapt this procedure to our multi-right context in the following way: After the experiment, the whole sample is randomly partitioned into seven subsamples (the non-transferable exclusive license to reproduce does not participate in this partitioning, as we buy this license from every eligible participant at a price of \$10). Each participant is assigned to only one of those subsamples. The mechanism is applied within the subsample. This makes sure that we get a credible decision from each participant for each of the seven cells.

As is well-known, second-price auctions are vulnerable to collusion (see only Marshall and Marx 2007). However, participants in our design come from all over the world, which is known to them, so that collusion is of no practical concern. There are theoretical problems with incentive compatibility if more than one good is auctioned off simultaneously. These problems are also ruled out by our design. While we get choices for seven different (sets of) rights, each participant knows that only one of the seven cells will be payoff-relevant. We, thus, rely on the strategy method (Selten 1967) to preserve incentive compatibility. Brandts and Charness (2011) and Fischbacher, Gächter et al. (2012) show that this approach is not only theoretically, but also behaviorally valid.

\section{Data Collection}

We ran the experiment in two waves, using exactly the same software and website. The first wave ran from July 7 to July 9, 2015. In this wave, we asked for photos on the topic of "water.” The second wave ran from July 27 to August 12, 2015. In this wave, we asked for photos on the topic of "nature." We had two reasons for running a second wave: We wanted to increase the overall sample size and, more importantly, in the second wave we oversampled participants from the U.S., France and Germany. With the second wave, we in particular want to test our second hypothesis.

Table 2 contains information about the sample. A total of 468 individuals participated in our field experiment, 149 in the first and 319 in the second wave. In the first wave, 39 submissions were excluded by the jury as off the topic. This was the case for another nine submissions in the second wave. ${ }^{9}$ Eight submissions were from the experimental team (mainly to test the software). Eleven submissions were from individuals who participated twice, either in the same wave or in the first and the second waves. In the interest of preserving statistical inde- 
pendence, we only kept the first submission from such individuals. Especially in the second wave, a sizeable fraction (29.15 \%: 93 participants) left the website after uploading the picture. We will come back to this observation, which is inherent in running a field experiment over the Internet, in the results section. In the first wave, $12.08 \%$ (18 participants) did so. We lost a further three (first wave) and 37 (second wave) participants because they dropped out after reading the instructions. Finally, we did not receive country information from nine participants (first wave) and 39 participants (second wave). This leaves us with a net sample of 202 participants who completed the whole experiment (73 from the first and 129 from the second wave). Appendix B presents some of the photos that were submitted during the experiment.

\begin{tabular}{|l|l|l|l|}
\hline & wave 1 & wave 2 & total \\
\hline total submissions & 149 & 319 & 468 \\
\hline off topic & 39 & 9 & 48 \\
\hline internal & 6 & 2 & 8 \\
\hline duplicate & 1 & 10 & 11 \\
\hline only photo & 18 & 93 & 111 \\
\hline only instructions & 3 & 37 & 40 \\
\hline only rights & 9 & 39 & 48 \\
\hline selected & 73 & 129 & 202 \\
\hline
\end{tabular}

Table 2: Gross and Net Sample

56 participants from whom we have full information come from the United States, 21 from France and 43 from Germany. We, thus, have about the same number of participants who live in a legal system that does not fully protect moral rights, and from one of the two prominent legal orders that do. The remaining participants come from Australia (2), Bosnia Herzegovina (30), Canada (1), Chile (1), Egypt (6), Georgia (1), Greece (7), Hungary (3), India (3), Mexico (4), Morocco (3), the Philippines (2), Poland (1), Romania (2), South Korea (1), Switzerland (4), Thailand (6), the Netherlands (1), Turkey (1), the UK (2) and Vietnam (1). The left-hand panel of Figure 1 breaks the sample down by gross domestic product (using the World Bank 2014 data). The distribution is bimodal. A substantial fraction of our participants come from relatively poor countries. The second peak is from the three wealthy countries that we oversampled. The right-hand panel of Figure 1 alternatively uses the World Bank’s (2014) Rule of Law Index. A lot of mass is at the higher end in this distribution, reflecting that we oversampled participants from three Western countries. 

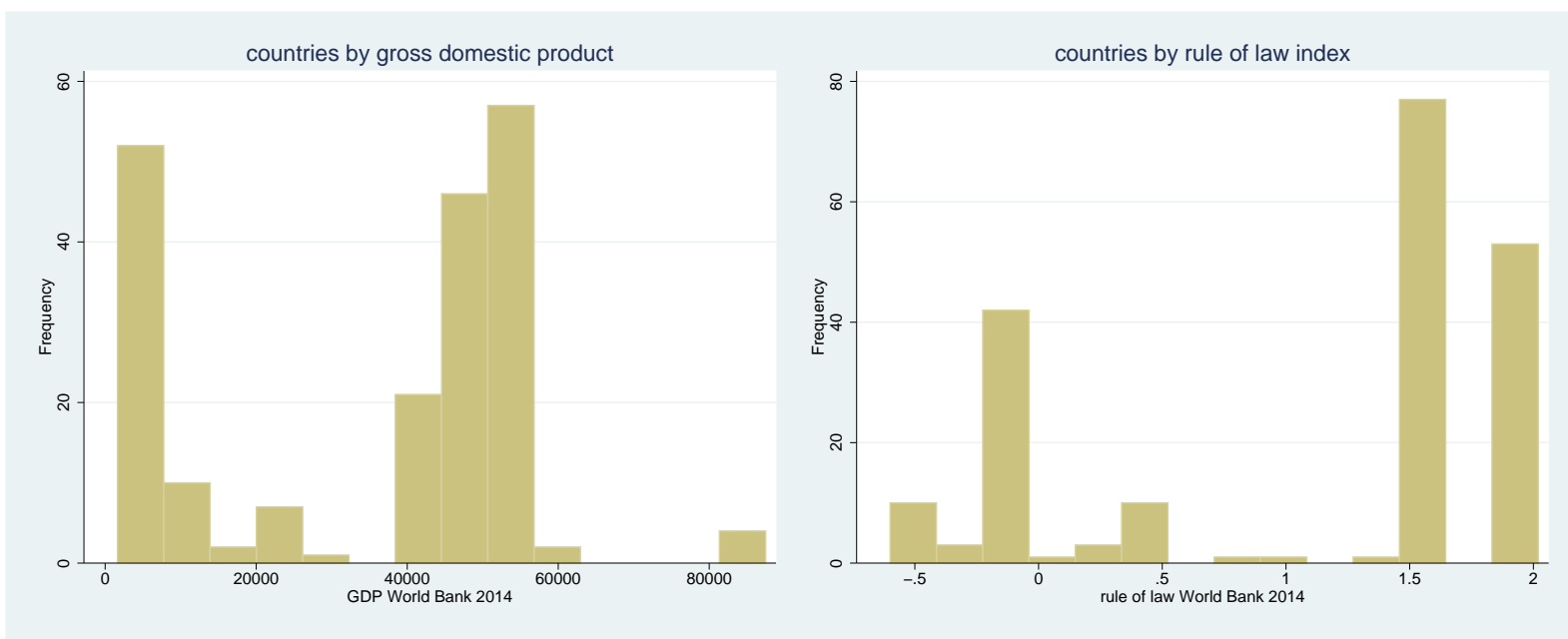

Figure 1: Sample by Gross Domestic Product and Rule of Law GDP is GDP per capita

In the final sample, 129 participants (64.82\%) are female. ${ }^{10} 79$ participants are between 16 and 20 years old, and one participant is even younger, 35 participants are between 21 and 25, 30 participants are between 26 and 30, 32 participants are between 31 and 40, five participants are between 41 and 50 and two are older than 60 years old. ${ }^{11} 70$ participants hold a high school degree, 45 a college degree, 31 a bachelor's degree, 15 a master's degree, 1 a PhD and 35 hold none of those degrees. ${ }^{12} 117$ participants selected classified themselves as "amateurs," 68 as "beginners" and 14 as "professionals." 23 participants selected said they spend an hour per week at most taking photos, 61 said they take between 1 and 2 hours, 63 said between 2 and 5 hours, 29 said between 5 and 10 hours and 24 said more than 10 hours. ${ }^{14} 156$ participants selected reported that they had never participated in a photography contest, while 44 said they had. ${ }^{15}$

In line with the design of the experiment, most participants earned $\$ 10$ for their participation and for granting us a non-transferable exclusive license to reproduce their photo. Auction winners earned between $\$ 15$ and $\$ 100$ (\$39.07 on average). ${ }^{16}$ Overall, participants earned an average of $\$ 11.88$. If participants were willing to grant us several of the moral rights we asked, they

10 From three participants selected, we have country information, but do not know their gender. This applies to one participant each from Bosnia-Herzegovina, Germany and Switzerland.

1118 participants selected have not given us age information, one from France, seven from Germany, and ten from the United States.

12 We do not have degree information from five participants selected: one from France, three from Germany and one from Thailand.

13 Three participants selected did not give us this classification: one each from Georgia, Germany and the United States.

14 Two participants selected from Germany did not reveal this information.

15 Two participants selected from Germany did not share this information with us.

16 The subsamples which we created to overcome problems associated with multiple-item second-prize auctions (see supra Section III) had 11 (water) and 20 (nature) participants each. On average, only $28.6 \%$ of participants in a subsample placed a bid for the respective right. If only few participants place a bid, the successful bidder may earn up to $\$ 100$ if the willingness to accept (WTA) if the second-lowest bidder was $\$ 100$, even if the successful bidder's WTA is only $\$ 5$. The relatively high average payment is therefore a result of the small cell sizes in which we run our seven reverse second-prize auction. The payment size does not affect the incentive-compatibility of our mechanism. 
typically demanded substantially different prices for the individual rights. ${ }^{17}$ This alleviates concerns that our participants may not have understood the auction mechanism we used.

\section{Results}

\section{A. The Valuation of Moral Rights}

To test our first hypothesis, we pool the data over all countries and both waves. To the extent that we find wave effects, we report them separately. Descriptively, the willingness to trade any right transcending the non-transferable exclusive license to reproduce is not pronounced. In relative terms, participants are most likely to trade the transferable exclusive right (38.19 $\%)$. Interestingly, participants are more likely to sell the right to change the picture if it, additionally, is transferable (33.33\%). This is slightly more likely than authorizing the use of the picture without mentioning their name (30.30\%). Participants are a little less likely to trade the same right if it is transferable (25.13\%). They are more inclined to trade the integrity right (23.50\%) than the deletion right (20.40\%) if these rights are not transferable. Participants are strongly opposed to trading the transferable deletion right: Only $18.00 \%$ of them are willing to sell this right. ${ }^{18}$ Actually, the large fraction of participants who do not complete our experiment may suggest that the reservation to trade moral rights is even more pronounced than expressed in these figures. However, we do not, of course, know the motives for dropping out and only mention this observation in passing.

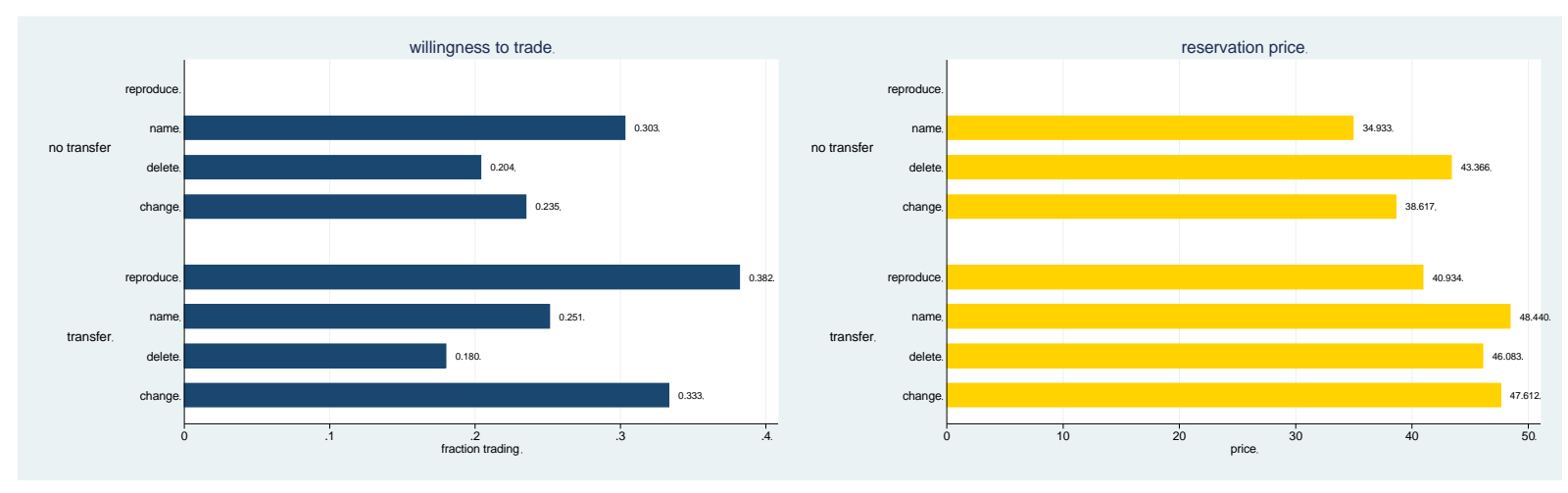

Figure 2: Descriptives (all data)

17 For each participant who is willing to grant us rights $(\mathrm{N}=184)$, we determine the standard deviation of the requested prices per participant. The mean of these standard deviations is 17.39 , the standard deviation of these standard deviations is 16.79 .

18 Results change slightly if we also count participants as willing to trade who ticked the respective box on the computer screen, but later did not indicate the price at which they would be willing to trade. We then find $39.11 \%$ for the right to transfer the exclusive license to reproduce, $31.68 \%$ for the nontransferable attribution (26.24 \% if transferable), $24.26 \%$ for the non-transferable integrity right (33.66 \% if transferable) and $20.79 \%$ for the non-transferable deletion right (18.81\% if transferable). Results also change slightly if we count participants as willing to trade if they indicated a price, but did not explicitly tick the box that asked them whether they want to trade the right in question. We then find $37.62 \%$ for the right to transfer the exclusive license to reproduce, $29.70 \%$ for the non-transferable attribution right (24.75\% if transferable), $23.27 \%$ for the non-transferable integrity (33.17\% if transferable) and $20.30 \%$ for the non-transferable deletion right (17.82 \% if transferable). 
We had seven choices from each participant. ${ }^{19} \mathrm{We}$, thus, have panel data. The Hausman test turns out significant, which is why we must estimate a fixed effects model to avoid bias. Our dependent variable is binary, which might call for a logit model. However, we would then lose the data from participants who are unwilling to trade any additional right. We react by estimating a linear probability model. It has the additional advantage that coefficients can be directly interpreted as the marginal decrease in the probability that the respective right trades. The reference category is the transferable exclusive right to reproduce the photo. ${ }^{20}$ Note that this is not a moral right. Hence, participants are generally hesitant to trade additional rights, even if the non-pecuniary "moral" dimension is not affected. The constant predicts that only $37 \%$ of all participants will trade this right. Interpretation should focus on the differences between willingness to trade an additional non-moral right (the transferable exclusive license to reproduce) and the willingness to trade one of the $3 \times 2$ moral rights. This difference can be read directly off the treatment coefficients.

The regression expects all other rights to trade even less, except for the transferable integrity right. Wald tests show that the additional possibility of transferring a right only affects willingness to trade for the integrity right $(\mathrm{p}=.0146)$. If this right was transferable, participants would be more likely to trade the right. This suggests that participants see more reason to change a photo if the current license holder cannot predict what the photo will be needed for in the future. Participants are even more hesitant to allow the license holder to destroy the photo than using it without mentioning their name $(\mathrm{p}=.0204)$. If both rights may be transferred, this difference is only weakly significant $(\mathrm{p}=.0874)$. Participants are more likely to trade a transferable integrity right than (1) a transferable attribution right $(\mathrm{p}=.0463)$ and $(2)$ a deletion right $(\mathrm{p}=.0002)^{21}$

19 Recall that participants mechanically granted a non-transferable exclusive license to reproduce at a price of $\$ 10$ by participating in the field experiment. Therefore, while Table 1 features eight cells, we only have seven choices per participant.

20 We cannot use the willingness to pay for a non-transferable exclusive right as the reference category, since we oblige every participant to grant this right and fix its price at $\$ 10$.

21 If we rerun the same model as in Table 3, but interact all rights with the second wave of the experiment, at conventional levels, we only find a significant interaction with the transferable integrity right. In the second wave, participants are significantly more likely to grant this right $(\mathrm{p}=.009)$. Due to a programming mistake on the web site interface, we have several price data points even though the participant did not want to trade the respective right. We take these cases out, leading to $\mathrm{N}=1398$ instead of 1414 . 


\begin{tabular}{|l|l|}
\hline attribution & $\begin{array}{l}-.085^{\star} \\
(.041)\end{array}$ \\
\hline attribution transfer & $\begin{array}{l}-.132^{\star \star} \\
(.041)\end{array}$ \\
\hline deletion & $\begin{array}{l}-.180^{\star \star \star} \\
(.041)\end{array}$ \\
\hline deletion transfer & $\begin{array}{l}-.202^{\star \star \star} \\
(.041)\end{array}$ \\
\hline integrity & $-.150^{\star \star \star}$ \\
& $(.041)$ \\
\hline integrity transfer & -.050 \\
& $(.041)$ \\
\hline cons & $.384^{\star \star \star}$ \\
& $(.029)$ \\
\hline $\mathrm{N}$ & 1398 \\
\hline $\mathrm{p}$ model & $<.0001$ \\
\hline
\end{tabular}

Table 3: Treatment Effect on Willingness to Trade

fixed effects linear probability model

attribution: right to use the picture without mentioning author

deletion: right to delete the picture

integrity: right to change the picture

transfer: right is transferable

standard errors in parenthesis

${ }^{\star * *} p<.001,{ }^{* *} p<.01,{ }^{*} p<.05,{ }^{+} p<.1$

We, thus, support the first statement of the first hypothesis and conclude:

Result 1: Only a minority of participants are willing to trade moral rights.

The willingness to trade the attribution, deletion and integrity rights is even

less pronounced than the willingness to grant a transferable exclusive license to reproduce.

The design of our experiment fixes the price of the non-transferable exclusive license to reproduce at $\$ 10$. As we have just reported, many participants are not willing to trade further reaching rights at all. But even if they are, the right-hand panel of Figure 2 shows that they ask for considerably higher prices. If we pool the data from both waves, participants demand an average of $\$ 34.93$ for the attribution right, \$38.62 for the integrity right and \$43.37 for the deletion right. On average, all prices are even higher if the respective right is transferable. For an exclusive license, participants then request an average of $\$ 40.93$, $\$ 48.44$ for the transferable attribution right, $\$ 46.08$ for the transferable deletion right and $\$ 47.61$ for the transferable integrity right. ${ }^{22}$

Recall that the transferable exclusive license to reproduce is not a moral right. It is the reference category in the regressions of Table 4. Hence, the constant predicts that participants who are at all willing to grant the transferable exclusive license to reproduce will ask for a much

22 Again, results change slightly if we also use price data from participants who have not explicitly ticked the box that asked them whether they are happy to trade the right in question. We then find that participants demanded an average of $\$ 33.67$ for the attribution right, $\$ 37.14$ for the integrity right and $\$ 42.57$ for the deletion right. On average, all prices are even higher if the respective right is transferable. Participants then requested an average of $\$ 40.60$ for an exclusive license to reproduce, $\$ 47.69$ for the attribution right, $\$ 44.29$ for the deletion right and $\$ 47.61$ for the integrity right. 
higher price than for a non-transferable exclusive license to reproduce. ${ }^{23}$ Again, for our research question, the differences between the constant and the treatments that involve a moral right are critical, i.e. the coefficients of our six moral rights treatments. When we pool the data over the two waves, we do not find any significant treatment effects for non-transferable moral rights (Table 4). This suggests that, for such rights, the critical issue is willingness to trade (see again Table 3), not the size of the compensation. This is different if, additionally, the moral right is transferable. The regression predicts that participants who are at all willing to trade those rights demand an extra amount of more than $\$ 10$. By the design of the experiment, we only measure reservation prices for participants who declare their willingness to trade the respective right. The correct interpretation of the regressions in Table 4 is, therefore, a conditional reservation price. It is conditional on the (observed) willingness to trade. As mentioned, we cannot say whether the remaining participants have a reservation price for the respective right that is above the cutoff of $\$ 100$, or whether their reservation price is infinite, i.e. whether they would never sell whatever price is offered. We again report fixed effects models.

While wave effects are unimportant for the decision to trade, they matter for reservation prices. Note that model 1 in Table 4 includes participant fixed effects. Hence, wave effects are automatically partialled out, which avoids omitted variable bias. It seems, nonetheless, worth noting that these effects exist. This is why we also report separate regressions for each wave. If we analyze the data from the first wave in isolation, we only find a very strong and significant constant. In this wave, participants who were at all willing to trade any additional moral right wanted to be compensated by a large amount of money. This general effect dominates all differences between moral rights. We do, however, find such differences in the second wave.

On first reading, this seems to suggest that the topic "water" elicited a stronger sense of ownership in photographers than the topic "nature." However, models 4 and 5 of Table 4 show that the apparent wave effects actually conceal a demographic effect. If, instead, we partition the data by the gross domestic product of the country of residence, the differences are even stronger. Treatment effects in the pooled regression are almost exclusively driven by the choices of participants in industrialized countries (see again Figure 1). ${ }^{24}$ The apparent wave effect results from the fact that we oversampled participants from these countries in the second wave. Since treatment effects on reservation prices are confined to transferable rights, this suggests that participants from countries with a well-functioning market economy consider a transferable moral right as a commodity and as one they want to be priced highly.

23 Again, the Hausman test turns out significant, which is why we report a fixed-effects model.

24 Results look very similar if, instead, we partition the data by residents from a country with a rule of law index below or above 1, see Figure 1 for this measure. These additional regressions are available from the authors upon request. 


\begin{tabular}{|l|l|l|l|l|l|}
\hline & pooled & wave 1 & wave 2 & GDP < 40000 & GDP > 40000 \\
\hline attribution & 5.400 & 6.677 & 4.135 & 4.331 & 5.597 \\
& $(4.156)$ & $(7.328)$ & $(5.077)$ & $(7.724)$ & $(4.936)$ \\
\hline attribution transfer & $11.806^{\star \star}$ & 7.267 & $14.536^{\star \star}$ & 5.891 & $15.167^{\star \star}$ \\
& $(3.567)$ & $(6.680)$ & $(4.182)$ & $(6.258)$ & $(4.371)$ \\
\hline deletion & 4.037 & 6.281 & 2.296 & -3.094 & 7.887 \\
& $(4.284)$ & $(7.397)$ & $(5.297)$ & $(8.056)$ & $(5.065)$ \\
\hline deletion transfer & $12.745^{\star \star}$ & 7.686 & $15.758^{\star \star}$ & 6.831 & $16.311^{\star \star}$ \\
& $(3.949)$ & $(7.312)$ & $(4.653)$ & $(6.568)$ & $(5.044)$ \\
\hline integrity & 1.861 & 3.775 & -.708 & .193 & 2.012 \\
& $(4.529)$ & $(7.178)$ & $(6.041)$ & $(7.585)$ & $(5.798)$ \\
\hline integrity transfer & $11.742^{\star \star \star}$ & 6.311 & $14.258^{\star \star \star}$ & 6.282 & $14.262^{\star \star \star}$ \\
& $(3.215)$ & $(6.355)$ & $(3.691)$ & $(6.262)$ & $(3.739)$ \\
\hline cons & $36.229^{\star \star \star}$ & $46.734^{\star \star \star}$ & $30.369^{\star \star \star}$ & $42.642^{\star \star \star}$ & $32.988^{\star \star \star}$ \\
& $(2.326)$ & $(4.151)$ & $(2.812)$ & $(4.317)$ & $(2.757)$ \\
\hline $\mathrm{N}$ & 377 & 135 & 242 & 133 & 244 \\
\hline $\mathrm{p}$ model & .0041 & .885 & .0017 & .8377 & .0023 \\
\hline
\end{tabular}

Table 4: Treatment Effect on Reservation Prices

\begin{tabular}{|c|}
\hline $\begin{array}{l}\text { linear fixed effects } \\
\text { bution: right to use the picture without mentioni } \\
\text { deletion: right to delete the picture } \\
\text { integrity: right to change the picture } \\
\text { transfer: right is transferable } \\
\text { GPD is GDP per capita } \\
\text { standard errors in parenthesis } \\
\star \star \star p<.001,{ }^{\star \star} p<.01,{ }^{\star} p<.05,{ }^{+} p<.1\end{array}$ \\
\hline
\end{tabular}

To this extent, we support the second statement of Hypothesis 1 and conclude:

Result 2: Participants who are at all willing to trade the attribution, deletion or integrity rights ask for substantial financial compensation.

\section{B. Different Legal Traditions}

As described in Section 1, copyright law on both sides of the Atlantic treats moral rights very differently. While French and German copyright laws provide for a strong protection of moral rights, U.S. copyright law only has some minimal protection of these rights. We want to learn whether these different legal traditions reflect or have shaped the preferences of authors residing in these different countries.

Strictly speaking, the identification of a causal effect requires random variation. To test our first hypothesis, we could ourselves create this variation by simultaneously exposing the participants of our field experiment to seven different choice problems. Since participants did not know in advance which of these choices would be payoff-relevant, we can exclude that their choices determine their preferences (so there is no problem of reverse causality). Since we have participants from all over the world, this also minimizes the danger of omitted variable 
bias, to the extent this can be done in a field experiment. ${ }^{25}$ Identification is more precarious for our second hypothesis. Demographic variables, by their very nature, cannot be randomly assigned. We cannot randomly turn a nation-free individual into being either American or Continental European. We, therefore, have no way to disentangle the direction of causality. If we find differences, they could either result from differences between American and European legal cultures - to which legislators react - or differences could result from the fact that legal traditions differ - which have shaped different attitudes towards intellectual property. What we can possibly identify though, is a significant difference in the reaction of participants from either context to our manipulation. We can, thus, investigate whether the interaction between law and culture determines differences in choices.

Even this more modest object of investigation is more involved than a standard experimental manipulation. We can be reasonably sure that the distinction between American law and culture, on the one hand, and continental European law and culture, on the other hand, is sufficiently well proxied by the country of residence reported by our participants. Strictly speaking, we cannot exclude that Europeans have participated in the experiment who currently live in the U.S., and vice versa. But we have 56 participants indicating the U.S. as their country of residence and 63 indicating Germany or France. It is very unlikely that a large fraction of them would actually have to be classified as appertaining to the opposite culture. ${ }^{26}$ It is more difficult, though, to be sure that a possible difference between those reporting a U.S. residence from those reporting a Continental European residence is really a difference in law and culture. Such differences could be spurious, because the two subject pools differ in other relevant respects. The summary statistics in Table 5 suggest that there may indeed be an issue with sample composition. Mean age and the fraction of participants who classify themselves as beginners are virtually identical. However, we had even more female participants in the U.S. On the European continent, the certified level of education was higher. In the U.S., the average participant spent more time per week taking photos. On the European continent, more participants had previously submitted photos to contests. We readily admit all these potential competing explanations. In principle, we could treat them as potential selection on observables and react by presenting regressions that use this demographic information as control variables. However, since we use individual fixed effects in all regressions, this observed (and any additional unobserved) heterogeneity is automatically filtered out.

25 One potential source of bias is the price for the higher external validity provided by the field experiment: We cannot exclude that those individuals attracted by the experiment care in ways about the nonpecuniary dimension of creativity that differ from those who have not considered participating. We, thus, did not have the possibility to randomly assign individuals from a larger pool to be participants in our experiment. 


\begin{tabular}{|l|l|l|}
\hline & France/Germany & U.S. \\
\hline female & $74.19 \%$ & $87.50 \%$ \\
\hline age & 22.72 & 21.32 \\
\hline degree & 1.41 & 0.98 \\
\hline beginner & $57.14 \%$ & $57.14 \%$ \\
\hline hours & 2.94 & 4.38 \\
\hline contest & $21.31 \%$ & $14.29 \%$ \\
\hline
\end{tabular}

Table 5: Sample Characteristics in the U.S. and on the European Continent

Descriptively, while $39.3 \%$ of all participants in the U.S. are willing to trade the attribution right, only $25.4 \%$ of all participants on the European continent are prepared to do so. The difference is even more pronounced for the integrity right: $30.4 \%$ of the U.S. participants are willing to accept this, while only $12.7 \%$ do so on the European continent. The difference is small for the additional right to delete the photo. In the U.S., $23.2 \%$ of all participants are willing to sell this right, while $18.8 \%$ of the French and German participants are willing to do so. Differences are less pronounced if the additional right is transferable. With regard to the transferable exclusive license to reproduce the photo, $36.4 \%$ are willing to trade it in the U.S. and $40.3 \%$ on the European continent. Out of all participants with a residence in the U.S., $30.9 \%$ are willing to trade the transferable alteration right, versus $39.1 \%$ in Europe. Only $19.6 \%$ of the U.S. participants are prepared to trade a transferable attribution right, while 25.8 $\%$ of Europeans are happy to do so. Finally, $14.5 \%$ of the Americans are willing to give a transferable deletion right, while $15.9 \%$ of the Europeans are willing to do so. The most visible difference between the two subject pools concerns the effect of transferability. In the U.S., it has a clear dampening effect, while the effect is more nuanced on the European continent. Descriptively, Europeans are even more likely to trade the integrity right if it is transferable.

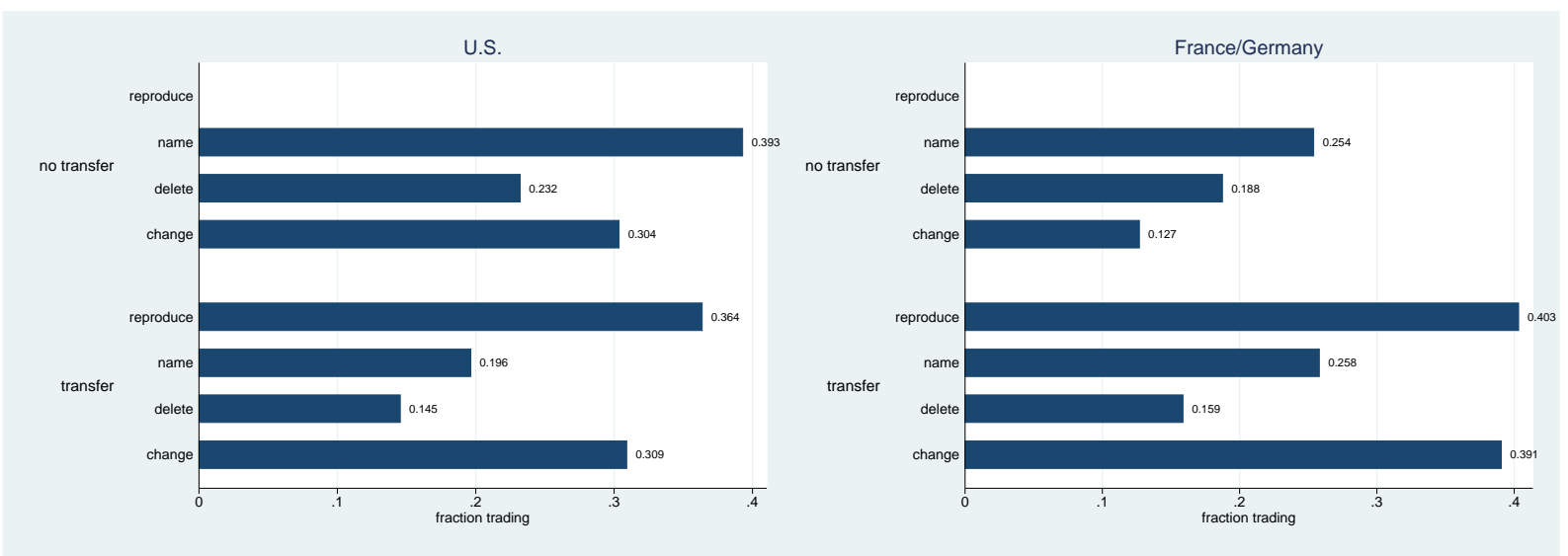

Figure 3: Willingness to Trade in the U.S. and in France/Germany

We have already pointed out that a fixed effects model is in order when analyzing the full data. By design, the fixed effect for each individual participant captures any demographic differences, even beyond differences we could control for: all individual characteristics stay constant for all seven choices made by each participant. As a result, the main effects of any such characteristics, and the country of residence, for that matter, drop out. We can, however, in- 
teract the different rights with country. These interaction effects are identified and capture systematic differences across countries in response to the character of the moral right in question. Using this approach, we indeed find that participants living in the U.S. are more than 20 $\%$ more likely to trade the integrity right $(\mathrm{p}=.035)$. They are also $19 \%$ more likely to trade the attribution right, but this country effect is only weakly significant $(\mathrm{p}=.079)$. The remaining descriptive differences are not significant.

\begin{tabular}{|l|l|}
\hline attribution & $-.157^{\star}$ \\
& $(.073)$ \\
\hline attribution transfer & $-.149^{\star}$ \\
& $(.073)$ \\
\hline deletion & $-.219^{\star \star}$ \\
& $(.073)$ \\
\hline deletion transfer & $-.247^{\star \star}$ \\
& $(.073)$ \\
\hline integrity & $-.284^{\star \star \star}$ \\
& $(.073)$ \\
\hline integrity transfer & -.016 \\
& $(.073)$ \\
\hline U.S.*attribution & $.188^{+}$ \\
& $(.107)$ \\
\hline U.S.*attribution transfer & -.017 \\
& $(.107)$ \\
\hline U.S. ${ }^{\star}$ deletion & .089 \\
& $(.107)$ \\
\hline U.S. ${ }^{\star}$ deletion transfer & .031 \\
& $(.107)$ \\
\hline U.S.*integrity & $.226^{\star}$ \\
& $(.107)$ \\
\hline U.S.*integrity transfer & -.042 \\
& $(.107)$ \\
\hline cons & $.386^{\star \star \star}$ \\
& $(.038)$ \\
\hline N & 830 \\
\hline p model & $<.0001$ \\
\hline & \\
&
\end{tabular}

Table 6: Treatment Effect on Willingness to Trade: U.S. vs. France and Germany fixed effects linear probability model

attribution: right to use the picture without mentioning author

deletion: right to delete the picture

integrity: right to change the picture

transfer: right is transferable

standard errors in parenthesis

${ }^{\star * *} p<.001,{ }^{\star *} p<.01,{ }^{*} p<.05,{ }^{+} p<.1$

With regard to the non-transferable attribution and integrity rights, we support the first statement of Hypothesis 2 and conclude:

Result 3: Participants with residence in the U.S. are more likely to trade non-transferable integrity and attribution rights compared to participants residing in either France or Germany. 
Descriptively, the mean price for the non-transferable attribution right is larger (\$33.18) in the U.S. than in France and Germany (\$24.75). By contrast, the compensation requested for the non-transferable deletion right is lower in the U.S. (\$33.54) than on the European continent (\$44.17). Descriptively, the most pronounced difference concerns transferable rights. If they go beyond the mere exclusive license to reproduce, photographers from the U.S. ask for a higher price (\$64.09 vs. $\$ 44.94$ for the attribution right, $\$ 65.63$ vs. $\$ 39.90$ for the deletion right and $\$ 57.94$ vs. \$37.92 for the integrity right).
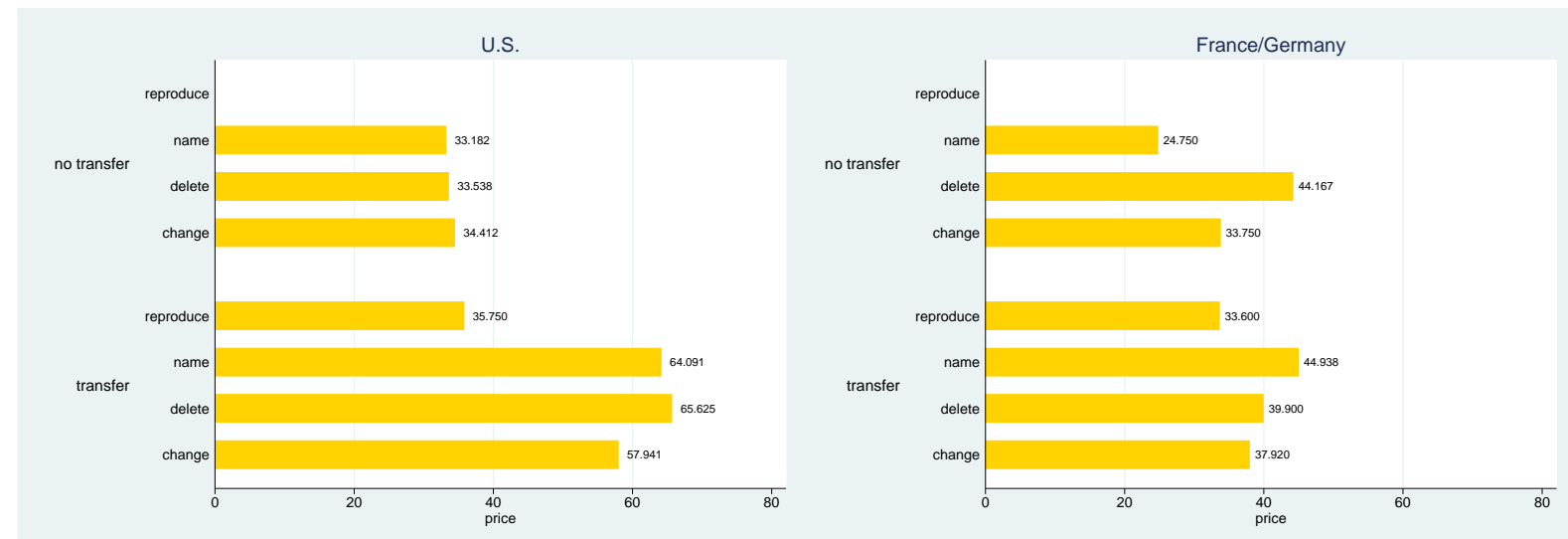

Figure 4: Reservation Prices in the U.S. and in France/Germany

As the regression in Table 7 demonstrates, only the country effects regarding the nontransferable attribution right and the non-transferable integrity right reach significance. We have a remarkable finding: While participants with residence in the U.S. are more likely to trade moral rights, they demand higher compensation if they do. 


\begin{tabular}{|l|l|}
\hline attribution & -6.527 \\
& $(7.426)$ \\
\hline attribution transfer & $10.810^{+}$ \\
& $(6.166)$ \\
\hline deletion & -3.479 \\
& $(7.394)$ \\
\hline deletion transfer & $15.978^{\star}$ \\
& $(7.361)$ \\
\hline integrity & $-20.209^{\star}$ \\
& $(9.655)$ \\
\hline integrity transfer & $9.782^{+}$ \\
& $(5.339)$ \\
\hline U.S.*attribution & $22.596^{\star}$ \\
& $(10.731)$ \\
\hline U.S.*attribution transfer & 11.661 \\
& $(9.472)$ \\
\hline U.S. ${ }^{*}$ deletion & 16.084 \\
& $(11.050)$ \\
\hline U.S. ${ }^{*}$ deletion transfer & 2.338 \\
& $(10.734)$ \\
\hline U.S.*integrity & $34.970^{\star *}$ \\
& $(12.803)$ \\
\hline U.S.*integrity transfer & 11.621 \\
& $(8.220)$ \\
\hline cons & $31.762^{\star \star \star}$ \\
& $(3.052)$ \\
\hline N & 220 \\
\hline p model & .0034 \\
\hline & \\
&
\end{tabular}

Table 7: Reservation Prices in the U.S. and in France/Germany

linear fixed effects

attribution: right to use the picture without mentioning author

deletion: right to delete the picture

integrity: right to change the picture

transfer: right is transferable

standard errors in parenthesis

${ }^{\star * *} p<.001,{ }^{* *} p<.01,{ }^{*} p<.05,{ }^{+} p<.1$

We, thus, reject the second statement of Hypothesis 2 and conclude:

Result 4: Photographers resident in the U.S. demand higher compensation for trading the non-transferable attribution and integrity rights compared to photographers resident in France or Germany.

\section{Discussion}

In a field experiment with worldwide participation, we elicit willingness to trade and reservation prices for three different moral rights (attribution, integrity and deletion) in two versions each (non-transferable, transferable). Our incentive-compatible design allows us to elicit true 
valuations. We find that only a minority of authors are willing to trade moral rights. If authors are willing to trade, they demand substantial financial compensation, in particular for transferable moral rights. U.S. authors are more willing to trade non-transferable attribution and integrity rights compared to French and German authors. If they are willing to trade, they also demand higher compensation than their French and German counterparts. These findings resonate with a normative debate over the expressive function of copyright law (Fromer 2012).

As any empirical analysis, our study has its limitations. First, while our field experiment overcomes external validity concerns that arise typically with laboratory experiments, our study still relies on a particular set of participants. Our recruitment method resulted in a mix of photographer types, with amateur photographers being in the majority. One might worry that copyright law is just not an important concern for the average Facebook user with an expressed interest in photography. If true, the results could (at least partly) be driven by a selection effect. Yet, attribution rights are of prime importance even in communities of free content sharing (as on many Internet platforms). While the licenses of the Creative Commons project, for example, enable authors to relinquish nearly all control over their work, authors typically retain at least the attribution right. Similarly, under many open source licenses, computer programmers require licensees to name the original author of the software code. Individual author contributions in Wikipedia can also be identified. Arguably, moral rights such as attribution and integrity are of even greater importance for the sharing economy than in the traditional media industry (Fisk 2006: 88-92, Sprigman, Buccafusco et al. 2013: 1398-1399, 1403, Bauer, Franke et al. 2016). Precisely because monetary rewards are excluded, moral rights are the only source of recognition.

Second, we conducted our field experiment with photographers. While we have no specific reason to think that the authors of other work categories have different attitudes towards moral rights, we cannot rule this out. As we had to limit the complexity of our experimental design, we did not directly investigate whether subjects have a preference for non-waivable and inalienable moral rights, compared to tradable rights.

Third, the design of our experiment makes moral rights salient. It could be that salience affects the reactions of our participants (from the rich literature, see only Bordalo, Gennaioli et al. 2012, Epstein and Segal 2000, Mehta, Strarmer et al. 1994, Shavitt and Fazio 1991). We cannot rule out that this has affected the measurement of willingness to accept. But we note that this is a price one has to pay for identification. We would otherwise not have had multiple observations per individual, and could not have filtered out any personal differences by way of fixed effects.

Fourth, our results are based on our participants playing a reversed second-price auction in an incentive-compatible way. This is predicted by rational choice theory, which we use as a baseline. We did not train our participants before the auction took place, as this would have impeded the cover story of our field experiment. However, the substantial variation in the 
prices demanded by each participant ${ }^{27}$ gives us confidence that participants have understood our second price auction.

Fifth, an alternative study design would give participants a choice between (a) protection of moral rights and (b) no protection of moral rights, but a higher license fee for their photo. Thereby, one could investigate whether participants are willing to reduce the money they receive in order to hold onto moral rights. Isn't this the question that matters normatively? ${ }^{28} \mathrm{On}$ experimental grounds, it is conceivable that participants would ask for less moral rights protection if they had to "pay" with a lower profit from selling the copyright. But on theoretical grounds, we disagree. Under a rational choice framework, our incentive-compatible design is equivalent to this alternative design. If both designs led to different results, it would most likely follow from an endowment effect (from the lively empirical debate, see only Kahneman, Knetsch et al. 1990, Korobkin 2014, Plott and Zeiler 2005, Klass and Zeiler 2013). Normatively, one may discuss whether willingness to pay or willingness to accept are relevant. But the fact that there is a difference between both does not invalidate the normative relevance of a revealed preference for moral rights. ${ }^{29}$

Sixth, our study is, of course, only one contribution to the normative debate on the desirability of moral rights. The legislator may see a conflict between the preference of authors for moral rights and the interests of other authors, third parties or society at large, such as a public interest in freeing art from the control of artists. An example of such conflict was the removal of the site-specific sculpture Tilted Arc by Richard Serra from Federal Plaza in downtown Manhattan, where the artistic vision of a minimalist artist collided with the public perception of the artwork (Adler 2009: 274). Much as exploitation rights are limited by fair use provisions in copyright law, the legislator may want to limit moral rights by provisions that reflect the preferences of other authors, third parties or the society at large.

Finally, even if moral rights should enjoy some protection, it may be unclear whether this warrants protection by a property right. Authors could protect their interests by contract. But, as mentioned before, contracts may be incomplete due to factual or legal constraints. They also require privity: Contracts would, at most, help with the direct licensee, not with third parties (Hansmann and Santilli 1997: 100-102). It may be difficult or even impossible for authors to have moral rights run with the copyrighted work and bind third party assignees by contract. In such an environment, legislators could resort to default setting. The classic transaction cost argument would plead in favor of moral rights protection as a majoritarian default (Easterbrook and Fischel 1991: 34-35). Sprigman, Buccafusco et al. (2013) argue against this solution since they find in their third experiment that defaults matter. In one condition, participants are entitled with an attribution right. They are asked for their willingness to accept (WTA) if their photo is published without their name. In the other condition, participants are

27 See supra text accompanying note 17.

28 We would like to thank Mark Lemley for raising this point.

29 At most, the normative relevance would be reduced in magnitude. On that issue, see our following discussion on defaults. 
not entitled with an attribution right. Sprigman, Buccafusco et al. (2013) find that the WTA is more than four times larger than the WTP. Addressing this concern was one of the reasons why we not only elicit a price, but also the categorical willingness to trade the respective moral right. As reported, there is no moral right which at least a majority of our participants is willing to trade in the first place. If the law does not protect the respective right, it ignores this preference altogether. The law would effectively propel authors to trade a right they wish to keep. However, our experiment shows that many authors are prepared to give up a substantial amount of money by not trading moral rights. Moreover, the prices our participants ask for trading any of the moral rights are substantial. Even if one followed the spirit of Sprigman, Buccafusco et al. (2013) and divided each of these prices by four to estimate a lower boundary, valuation for each of the moral rights would be sizeable.

More generally, our study provides empirical evidence of the revealed preferences of creators. This is an important building block for creating an empirically-informed theory of copyright protection. But this is not the only building block that is necessary for such theory. Some of the other building blocks are empirical in nature (such as the relative importance of protection by contract versus property right). Others are normative (such as the potential limitations to moral rights protection). We leave the integration of these different building blocks to future studies.

\section{Conclusion}

Our study presents results from a field experiment according to which authors are often unwilling to transfer moral rights, demand substantial prices if they are willing to give these rights, and according to which only limited variation between the preferences of authors from different countries exist.

The study provides four important insights for the policy debate on whether and to what extent copyright law should protect moral rights. First, we conclude from the limited willingness to trade moral rights and the substantial prices demanded if such trade occurs that many authors attach substantial value to the rights of attribution, integrity and deletion. If the law cares about the desires of authors, moral rights should receive some protection by copyright law.

Second, our results challenge the notion that copyright systems on both sides of the Atlantic should protect moral rights in different ways. In only two of six moral rights conditions, we found some evidence that U.S. participants were more willing to trade moral rights than French or German participants. No single moral right was traded by the majority of participants on either side of the Atlantic. If U.S. participants were willing to trade a moral right, they demanded even higher prices than their European counterparts.

Third, the study makes a methodological contribution to the literature on intellectual property. Our field experiment mitigates the typical external validity concerns raised with laboratory 
experiments, while still being able to identify causal relationships. Combined with our incentive-compatible elicitation mechanism, we propose a clean identification methodology which could also be used in other areas of intellectual property research.

Finally, our study challenges the notion that existing preferences of creators can be reconciled easily with orthodox profit-based theories of copyright protection. Our data suggest that such theories are incomplete. This calls for a behavioral enrichment of copyright theory. 


\section{References}

Adeney, E. (2006). The Moral Rights of Authors and Performers: An International and Comparative Analysis. Oxford, Oxford University Press.

Adler, A. M. (2009). Against Moral Rights. California Law Review. 97: 263-300.

Akerlof, G. A. and R. E. Kranton (2000). Economics and Identity. Quarterly Journal of Economics. 115: 715-753.

Al-Ubaydli, O. and J. A. List (2015). "Do Natural Field Experiments Afford Researchers More or Less Control than Laboratory Experiments?” American Economic Review 105: 462-466.

Ausubel, L. M. (2008). Auctions (Theory). The New Palgrave Dictionary of Economics. S. N. Durlauf and L. N. Blume. New York, Palgrave. 1: 290-302.

Bartling, B., E. Fehr and H. Herz (2014). The Intrinsic Value of Decision Rights. Econometrica. 82: 2005-2039.

Bauer, J., N. Franke and P. Tuertscher (2016). IP Norms in Online Communities: How Userorganized Intellectual Property Regulation Supports Innovation. Information Systems Research. 27: 724-750.

Becker, G. M., M. H. DeGroot and J. Marschak (1964). "Measuring Utility by a Singleresponse Sequential Method.” Behavioral Science 9: 226-232.

Bénabou, R. and J. Tirole (2011). Identity, Morals, and Taboos: Beliefs as Assets. Quarterly Journal of Economics. 126: 805-855.

Bordalo, P., N. Gennaioli and A. Shleifer (2012). Salience Theory of Choice Under Risk. Quarterly Journal of Economics. 127: 1243-1285.

Brandts, J. and G. Charness (2011). “The Strategy versus the Direct-response Method. A First Survey of Experimental Comparisons.” Experimental Economics 14: 375-398.

Clarke, E. H. (1971). “Multipart Pricing of Public Goods.” Public Choice 11: 17-33.

Easterbrook, F. H. and D. R. Fischel (1991). The Economic Structure of Corporate Law. Cambridge, Harvard University Press.

Epstein, L. and J. A. Segal (2000). Measuring Issue Salience. American Journal of Political Science. 44: 66-83.

Fischbacher, U., S. Gächter and S. Quercia (2012). The Behavioral Validity of the Strategy Method in Public Good Experiments. Journal of Economic Psychology. 33: 897-913. 
Fisk, C. L. (2006). Credit Where It's Due: The Law and Norms of Attribution. Georgetown Law Journal. 95: 49-117.

Fromer, J. C. (2012). Expressive Incentives in Intellectual Property Law. Virginia Law Review. 98: 1745-1824.

Groves, T. (1973). “Incentives in Teams.” Econometrica 41: 617-631.

Grünberger, M. and A. Dietz (2015). Germany. International Copyright Law and Practice. P. E. Geller, M. B. Nimmer and L. Bently. New Providence, LexisNexis. 2: GER-1210.

Hansmann, H. and M. Santilli (1997). Authors' and Artists' Moral Rights: A Comparative Legal and Economic Analysis. Journal of Legal Studies. 26: 95-143.

Hertwig, R. and A. Ortmann (2001). "Experimental Practices in Economics. A Methodological Challenge for Psychologists?” Behavioral and Brain Sciences 24: 383-403.

Kahneman, D., J. L. Knetsch and R. H. Thaler (1990). Experimental Tests of the Endowment Effect and the Coase Theorem. Journal of Political Economy, The University of Chicago Press. 98: 1325-1348.

Klass, G. and K. Zeiler (2013). Against Endowment Theory: Experimental Economics and Legal Scholarship. UCLA Law Review. 61: 2-64.

Korobkin, R. (2014). Wrestling with the Endowment Effect, or How to Do Law and Economics without the Coase Theorem. Oxford Handbook of Behavioral Economics and the Law. E. Zamir and D. Teichman. Oxford, Oxford University Press: 300-334.

Landes, W. M. and R. A. Posner (2003). The Economic Structure of Intellectual Property Law. Cambridge, Harvard University Press.

Lemley, M. A. (1997). The Economics of Improvement in Intellectual Property Law. Texas Law Review. 75: 989-1084.

Lemley, M. A. (2015). Faith-Based Intellectual Property. UCLA Law Review. 62: 1328-1346.

Listokin, Y. (2010). The Meaning of Contractual Silence: A Field Experiment. Journal of Legal Analysis. 2: 397-416.

Lucas, A., P. Kamina and R. Plaisant (2015). France. International Copyright Law and Practice. P. E. Geller, M. B. Nimmer and L. Bently. New Providence, LexisNexis. 1: FRA-1-159.

Marshall, R. C. and L. M. Marx (2007). Bidder Collusion. Journal of Economic Theory. 133: 374-402. 
Mehta, J., C. Strarmer and R. Sugden (1994). The Nature of Silence: An Experimental Investigation of Pure Coordination Games. American Economic Review. 84: 658-673.

Merges, R. P. (2011). Justifying Intellectual Property. Cambridge, Harvard University Press.

Nimmer, M. B. and D. Nimmer (2016). Nimmer on Copyright. New Providence, LexisNexis.

Plott, C. R. and K. Zeiler (2005). The Willingness to Pay - Willingness to Accept Gap, the "Endowment Effect," Subject Misconceptions, and Experimental Procedures for Eliciting Valuations. American Economic Review. 95: 530-545.

Rosenthal Kwall, R. (2010). The Soul of Creativity: Forging a Moral Rights Law for the United States. Palo Alto, Stanford University Press.

Selten, R. (1967). Die Strategiemethode zur Erforschung des eingeschränkt rationalen Verhaltens im Rahmen eines Oligopolexperiments. Beiträge zur experimentellen Wirtschaftsforschung. E. Sauermann. Tübingen, Mohr: 136-168.

Shavitt, S. and R. H. Fazio (1991). Effects of Attribute Salience on the Consistency between Attitudes and Behavior Predictions. Personality and Social Psychology Bulletin. 17: 506-517.

Spellman, B. A. and F. Schauer (2009). Artists' Moral Rights and the Psychology of Ownership. Tulane Law Review. 83: 661-678.

Sprigman, C. J., C. Buccafusco and Z. C. Burns (2013). What's a Name Worth?: Experimental Tests of the Value of Attribution in Intellectual Property. Boston University Law Review. 93: 1389-1435.

Strömholm, S. (1983). Droit Moral: The International and Comparative Scene from a Scandinavian Viewpoint. International Review of Industrial Property \& Copyright Law. 14: $1-42$.

Sundara Rajan, M. T. (2011). Moral Rights: Principles, Practice and New Technology. Oxford, Oxford University Press.

Sunstein, C. R., D. Kahneman, D. Schkade and I. Ritov (2002). "Predictably Incoherent Judgements.” Stanford Law Review 53: 1153-1216.

Tversky, A., S. Sattath and P. Slovic (1988). “Contingent Weighting in Judgement and Choice.” Psychological Review 95: 371-384.

Vickrey, W. (1961). “Counterspeculation, Auctions, and Competitive Sealed Tenders.” Journal of Finance 16: 8-37. 


\section{Appendix A: Instructions}

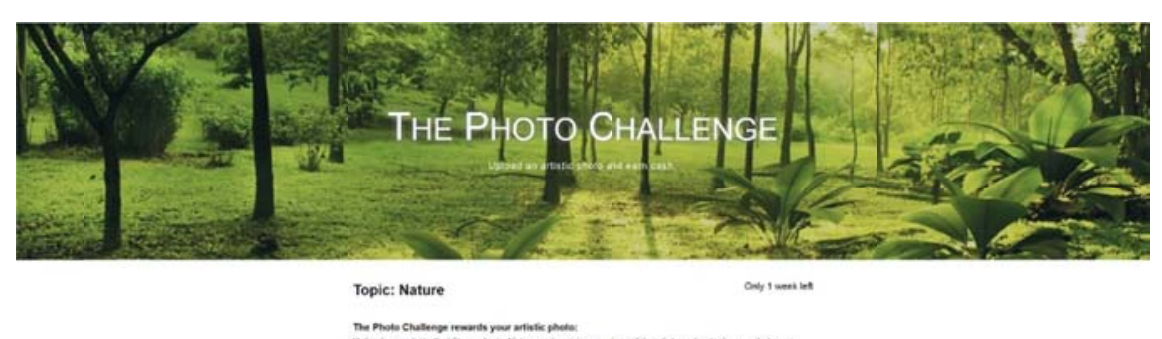

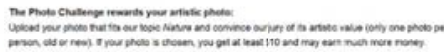

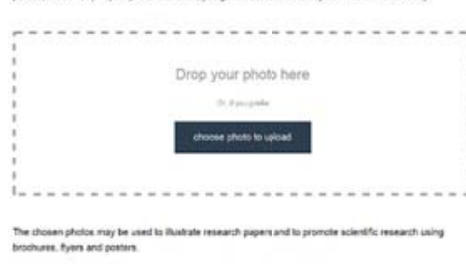

$\boldsymbol{E T H}_{\text {zürich }}$

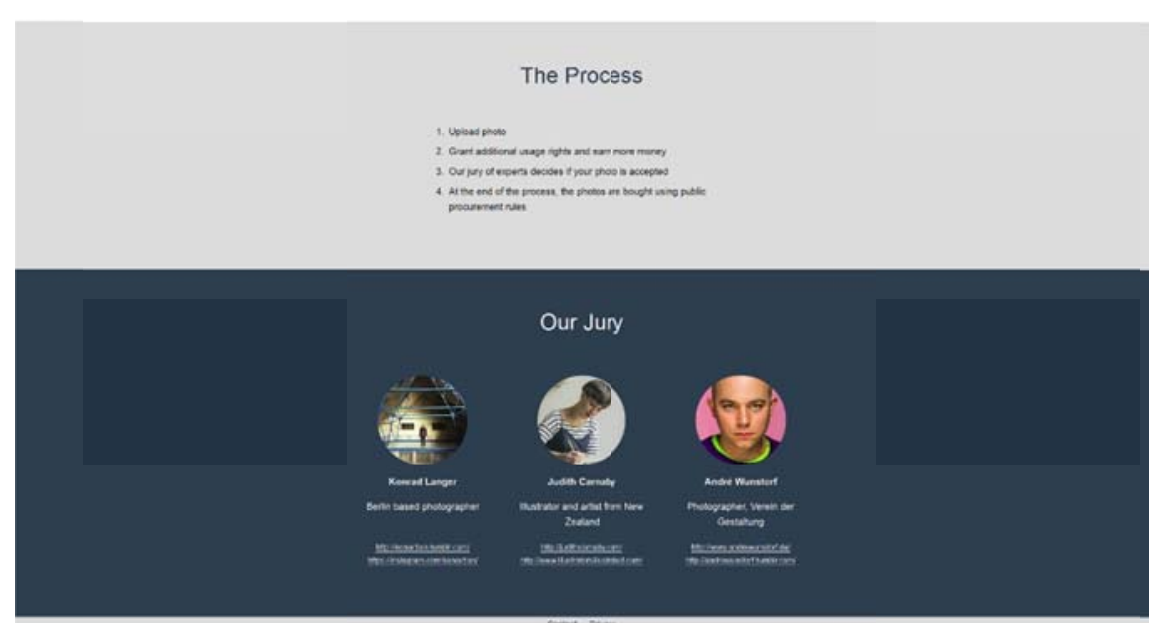

Sreenshot 1

\section{The Process}

This challenge is financed by public funds. Therefore, you need to understand the process and the terms. By understanding the process, you can maximize your income. You need to:

1. $\checkmark$ Upload a photo

2. Understand the process

3. Grant additional usage rights, and you may earn more money

4. Leave your email address (for the transfer of the payment through PayPal)

At the end of the challenge:

1. The jury of experts will evaluate your photo and exclude it if there is no connection to our topic 'Nature' or if the photo has no artistic value.

2. We will buy the photos using public procurement rules (will be explained later| 


\section{Grant Licenses}

Provided your photo has a connection to our theme 'Nature' and has some artistic value (as certified by our jury), you will definitely receive $\$ 10$.

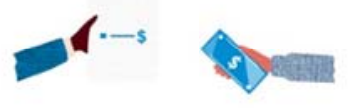

Additionally, you can sell more rights and earn up to $\$ 100$.

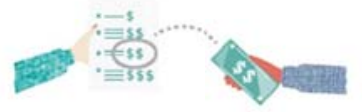

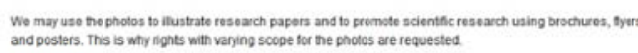

Back
Public Procurement Rules

IMPORTANT: The lowest offer is bought at the price of the second lowest offer

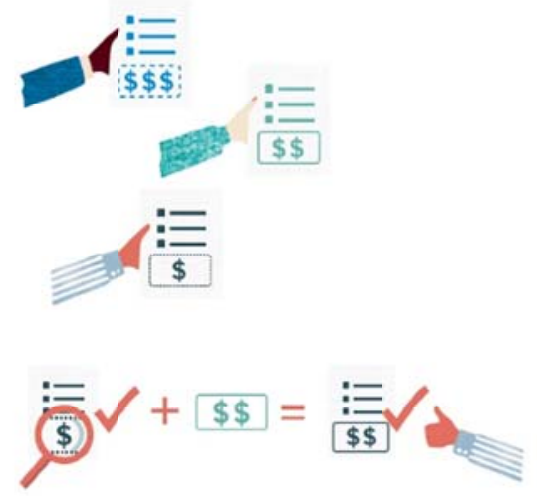

Here is an example: Let's say you offer to sell a particular usage right for your photo (more on this later) at a price of $\$ x$. The second lowest price offered by another participant is $\$ x+1$. In this case we will buy the right from you, but pay you $\$ x+1$.

Back Next 
Licenses You Can Sell

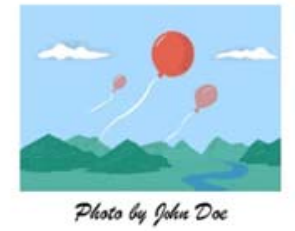

Exclusive license to use the photo

Always bought for $\$ 10$

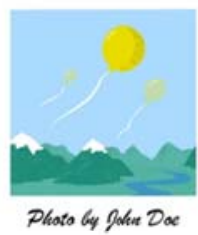

Exclusive license to use the

+ The right to change the photo with an image

processing software (format, content and size)

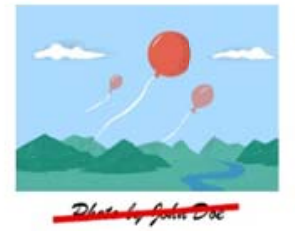

Exclusive license to use the photo

+ The right to use the photo without mentioning your name

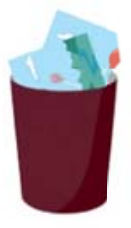

Exclusive license to use the photo

+ The right to delete the photo without your

authorization (you may not use the photo

afterwards)

\section{Right to Transfer License}

For all licenses mentioned on the previous screen, we are interested in the right to transfer the rights to third parties.
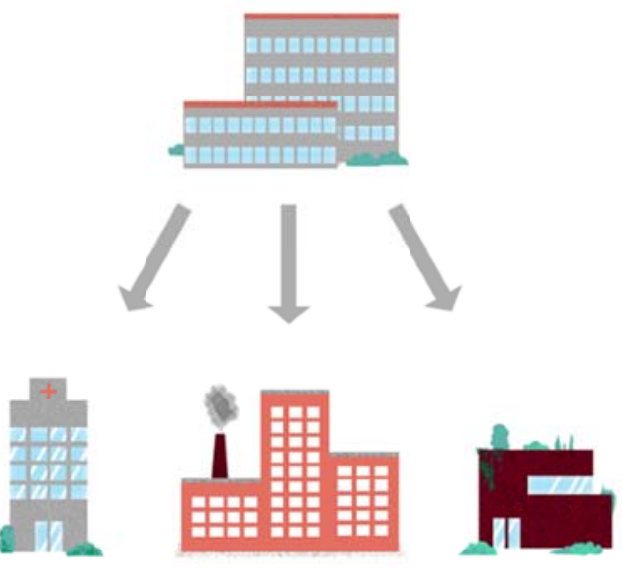

Back

Nex

Screenshot 5

Screenshot 6 


\section{Decision for Each Rights Category}

\section{Each selected photo is bought at a price of $\$ 10$ or more}

Once the challenge is finished, your photo will be randomly assigned to one of the seven rights categories which we are interested in

buying.

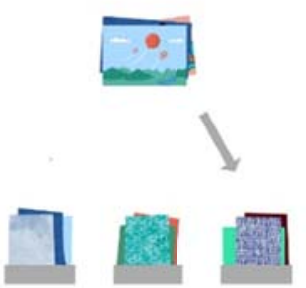

In each category, one photo will then be bought at a higher price than $\$ 10$ (the lowest offer will receive the second lowest price, see public procurement rules before).

\section{Summary}

A jury will evaluate your photo and exclude it if there is no connection to the theme 'Nature' or if the photo has no artistic value. Photos that meet these quality thresholds will not be ranked. The jury only decides whether a photo enters the challenge.

From each selected photo, an exclusive license to use the photo will be bought for $\$ 10$. Additionally, you can offer us more rights at a price you choose. We may use the winning photos to illustrate research papers and to promote scientific research using brochures, flyers and posters. This is why rights with varying scope for the photos are requested. We are interested in the following rights:

- The right to use the photo without mentioning your name

- The right to change the photo with an image processing software (format, content and size)

- The right to delete the photo without your authorization (you may not use the photo afterwards) - For each of these rights we are irterested in the possibility to transfer the right to third partes

As this challenge is financed by public funds, we will follow certain public procurement rules. The photo of the participant offering a particular right at the lowest price will be bought. This participant will receive the price offered by the participant offering the second lowest price in this category.

Your photo will be randomly assigned to one of the seven rights categories which we are interested in buying.

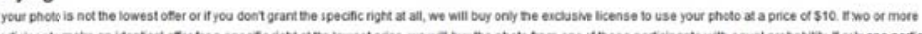

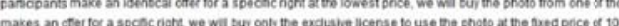

Each selected photo gets at least $\$ 10$.

IMPORTANT: Please click on "Grant Rights" and fill out the following forms. Only then you will participate in the Challenge. You are almost done.

$\square$ I have understood the process, the terms and the conditions

Gack Rights

Screenshot 7

Screenshot 8 


\section{Grant Additional Rights}

Please select the licenses you are willing to grant in addition to the exclusive license to use your photo and name the numeration for the license. You can ask as much as $\$ 100$.

\begin{tabular}{l} 
Exclusive license to use your photo \\
\hline We can only use the right by ourselves \\
My offer. s \\
$\square$ We can use the right by ourselves or transfer it to \\
others \\
\hline The right to delete your photo without \\
authorization (you may not use it afterwards). \\
$\square$ We can only use the right by ourselves \\
$\square$ We can use the right by ourselves or transfer it to \\
others.
\end{tabular}

The right to use your photo without mentioning your name.

$\square$ We can only use the right by ourselves

$$
\text { My ofter: } s
$$

$\square$ We can use the right by ourselves of transter it to others.

$$
\text { Ny ofler: } 5
$$

\section{The right to change your photo with an image} processing software.

$\square$ We can only use the right by ourselves

We can use the right by ourselves or transter it to others.

My ottor s :

\section{Payment Information}

If your photo is selected to participate in this Photo Challenge, we will transfer any payments to your PayPal account. Please leave the email address you use with your $\mathrm{PayPa}$ account.

Email Address: reound

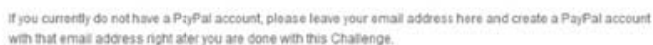

OK

Screenshot 9

Screenshot 10 


\section{Questionnaire}

You are almost done. We would greatly appreciate if you could answer the following questions

\begin{tabular}{l} 
In which country do live? \\
How old are you? \\
What is your gender? \\
\hline What is the highest educational degree you received? \\
\hline Have you ever sold one of your photos? \\
\hline In terms of photography experience, you see yourself as \\
\hline How many hours per week do you spend on photography?
\end{tabular}

Submit:
Thank you for participating in this photo

challenge

Your photo has been submitted to the jury. After this challenge has ended on the 6th of August, 2015 12:00:00 pm CET, we will inform you about the jury's decision and right transfers. We will then also transfer any payment to your PayPal account. 


\section{Appendix B: Submitted Photos}

The following photos are a selection of the photos that were submitted to the two field experiments.

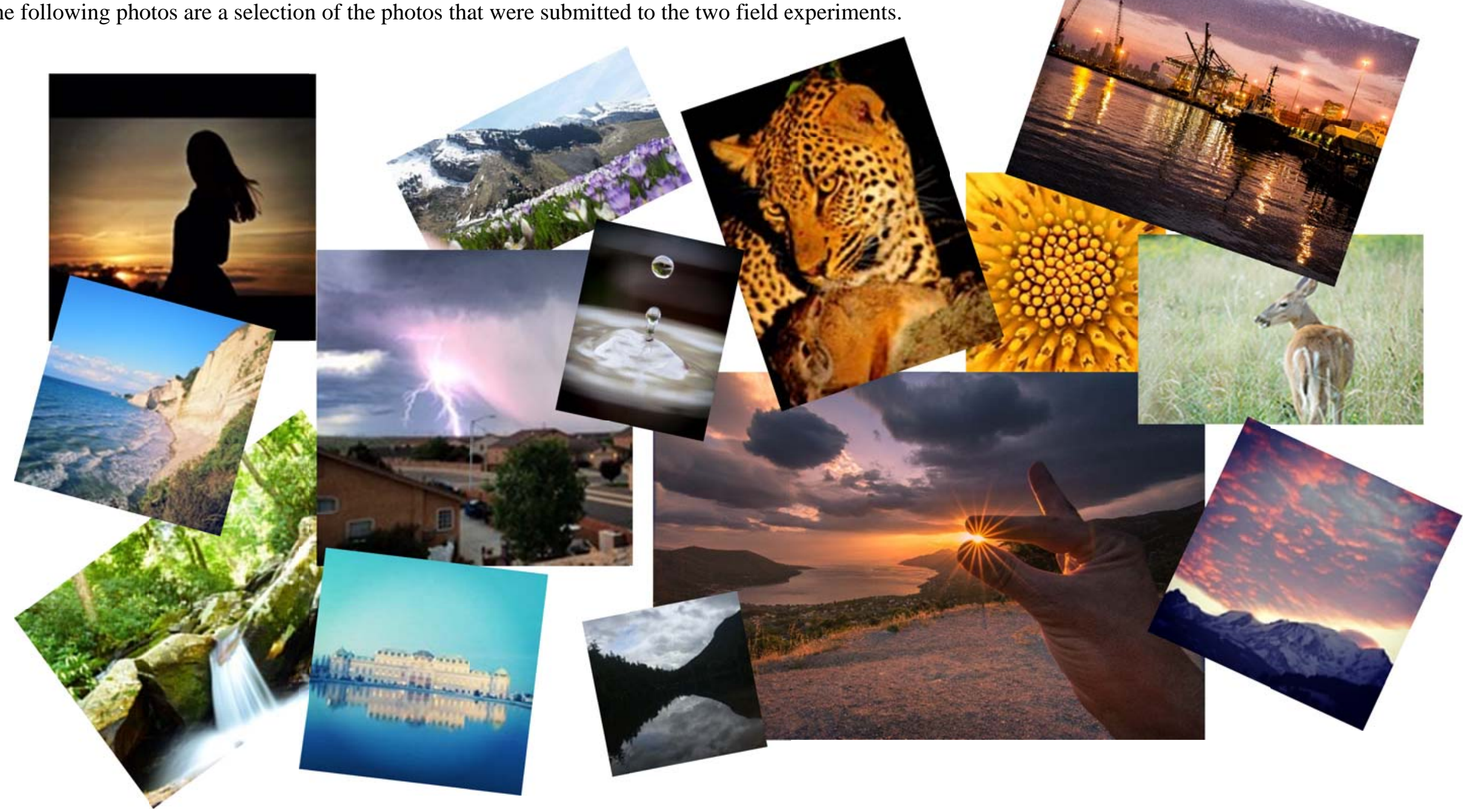

